\title{
Ultramicro Determination of Chloride
}

\author{
BY R. VISWANATHAN \\ Central Marine Fisheries Research Station, Mandapam Camp, South India
}

(Received 25 July 1950)

A simple technique has been described by Wigglesworth (1937) for the determination of chloride in as little as $0.3 \mu$ l. of fluid. This is based on the Volhard titration and has been used in this Laboratory since 1947 for the examination of fish and crustacean blood. While the results obtained were satisfactory, the tedious back titration and the comparatively impermanent end point were found to be inconvenient when a large number of biological samples had to be dealt with. The necessity was therefore felt for an alternative procedure which would be free from these limitations.

The method here described is an adaptation of the procedure outlined by Van Slyke \& Hiller (1947) suitably modified for use with drop-scale volumes.

\section{METHODS}

\section{Apparatus}

Waxed capillary pipettes and burettes of the type described by Wigglesworth.

Constriction 'Carlsberg' pipettes (Glick, 1935) with paraffined tips for delivering tungstate-phosphoric acid reagent, $\mathrm{KI}$ and starch solutions and of capacity 25,25 and $15 \mu$ l. respectively.

Reaction tubes. Glass tubes (length $20 \mathrm{~mm}$., internal diameter 3-4 $\mathrm{mm}$.) were coated internally with paraffin. Molten paraffin was allowed to solidify near the middle of the tube so that two cavities were formed, one of slightly larger capacity than the other. For stoppering the tube plasticine was used. After use, the paraffin could be pushed out of the tube and the latter rewaxed after suitable cleaning.

W.axed glass plates.

\section{Reagents}

Sodium tungstate $0.6 \%(w / v)$ in 0.15 M-phosphoric acid (Van Slyke \& Hiller, 1947).

Silver iodate (Sendroy, 1937). It is essential that this be kept in a brown-glass bottle and preserved in a desiccator.

Potassium iodide. $20 \mathrm{~g}$. KI in $100 \mathrm{ml}$. aqueous solution (containing a drop of dil. $\mathrm{NaOH}$ ). The solution is kept in a brown-glass bottle.

Starch. $1 \%(\mathrm{w} / \mathrm{v})$ solution of soluble starch in $20 \%(\mathrm{w} / \mathrm{v})$ $\mathrm{NaCl}$ (prepared fresh every week).

Sodium thiosulphate. Stock $0 \cdot 1 \mathrm{~N}-\mathrm{Na}_{2} \mathrm{~S}_{2} \mathrm{O}_{3}$ solution containing $1 \mathrm{~g}$. borax/l. of solution.

Standard sodium chloride solutions. Prepared by dissolving $\mathrm{NaCl}$ (Analar), previously dried at $120^{\circ}$ for $12 \mathrm{hr}$., in distilled water.

\section{Procedure}

Standard sodium chloride so utions. 5 ' units' of the chloride solution (about $1 \mu \mathrm{l}$.) were delivered from a graduated capillary pipette into the bigger chamber of the reaction tube, containing $25 \mu$ l. of tungstate-phosphoric acid reagent.
$1 \mu \mathrm{g}$. of $\mathrm{AgIO}_{3}$ was next tipped into the reaction chamber from the end of a horn spatula. This amount of iodate was enough to form a small layer at the bottom of the reaction chamber and could be fixed by practice. The reactants were stirred for 40 sec. with the sealed and paraffined end of a drawn-out glass tube, and the tube was stoppered with plasticine. The contents of the reaction tube were allowed to settle for $30 \mathrm{~min}$. Suitable samples were then pipetted on to the surface of a waxed glass plate, and $25 \mu \mathrm{l}$. of $20 \% \mathrm{KI}$ and $15 \mu \mathrm{l}$. of the starch indicator solution were placed alongside the sample drop on the glass plate. The KI and starch were mixed by an air jet and the drop mixture was directed on to the sample. The final drop mixture was titrated with $0.01 \mathrm{~N}$ $\mathrm{Na}_{2} \mathrm{~S}_{2} \mathrm{O}_{3}$ solution (prepared every 2 days by tenfold dilution of the stock solution) from a capillary burette. A water blank was run using 5 units of distilled water instead of the chloride solution, and this blank value was subtracted from the titres of the chloride solution.

The standard solution contained $1.4 \%$ (w/v) $\mathrm{NaCl}$ (239.3 m-equiv./l.) for the range 0.7-2.8\% $\mathrm{NaCl}(119.8 \mathrm{~m}$ equiv./1. to $478.6 \mathrm{~m}$-equiv./l.) and $0.35 \%(\mathrm{w} / \mathrm{v}) \mathrm{NaCl}(59.9$ $\mathrm{m}$-equiv./1.) for $\mathrm{NaCl}$ concentrations below $0 \cdot 7 \%$. The size of the sample used in the former range was such that the standardization titre was about 35 units of $0.01 \mathrm{~N}-\mathrm{Na}_{2} \mathrm{~S}_{2} \mathrm{O}_{3}$ solution. For the latter range the sample was thrice this size.

It was found convenient to have six reaction mixtures set up while six titrations were being carried out. In this manner twelve titrations could be completed in $2 \cdot 5 \mathrm{hr}$.

Chloride in blood serum. The procedure was similar to that described for standard $\mathrm{NaCl}$ solutions, but the estimations were carried out (in duplicate or in triplicate) at the 60$120 \mathrm{~mm}$-level, and where necessary the serum was diluted. Two samples of human blood serum analysed 98.31 and 97.59 mM-chloride respectively. The corresponding figures by the Wigglesworth method were 98.86 and $101.7 \mathrm{~mm}-$ chloride.

Recovery of $\mathrm{NaCl}$ added to serum varied from 95 to $103 \%$ in the range above $120 \mathrm{~mm}$; and from 99 to $107 \%$ in the range 18-60 mM (Table 3).

\section{RESULTS}

From Table 1 it is seen that the error does not exceed $3 \%$ in the range $120-600 \mathrm{~mm}$; while below $50 \mathrm{~mm}$ the accuracy is within $5 \%$ of the correct value.

In Table 2 are given the results obtained by periodical checks on the Wigglesworth method.

\section{DISCUSSION}

In Sendroy's (1937) micro method, it is necessary to correct for the solubility of silver iodate in varying chloride concentrations. In the drop-scale modification outlined above, this correction is substituted by the usual type of 'water blank' titre for the added 
Table 1. Drop-scale iodometry with standard sodium chloride solutions

\begin{tabular}{|c|c|c|c|}
\hline \multicolumn{3}{|c|}{$\mathrm{NaCl}$ (m-equiv./1.) } & \multirow{3}{*}{$\begin{array}{c}\text { No. of } \\
\text { determinations }\end{array}$} \\
\hline \multirow[b]{2}{*}{ Calc. } & \multicolumn{2}{|c|}{ Found } & \\
\hline & Mean & S.D. & \\
\hline 598.8 & $600 \cdot 6$ & $9 \cdot 56$ & 6 \\
\hline $479 \cdot 2$ & 483.0 & $2 \cdot 31$ & 6 \\
\hline $359 \cdot 4$ & 352.6 & $7 \cdot 63$ & 6 \\
\hline 119.8 & $116 \cdot 3$ & $3 \cdot 66$ & 6 \\
\hline 47.92 & $45 \cdot 83$ & $2 \cdot 29$ & 6 \\
\hline 35.94 & 34.95 & $2 \cdot 76$ & 6 \\
\hline 23.96 & 23.66 & $5 \cdot 33$ & 6 \\
\hline 11.98 & 11.93 & 0.53 & 6 \\
\hline
\end{tabular}

Table 2. Drop-scale Volhard estimations with standard sodium chloride solutions

\begin{tabular}{|c|c|c|c|}
\hline \multicolumn{3}{|c|}{$\mathrm{NaCl}$ (m-equiv./1.) } & \multirow{3}{*}{$\begin{array}{c}\text { No. of } \\
\text { determinations }\end{array}$} \\
\hline \multirow[b]{2}{*}{ Calc. } & \multicolumn{2}{|c|}{ Found } & \\
\hline & Mean & S.D. & \\
\hline 513.2 & $501 \cdot 7$ & $4 \cdot 87$ & 10 \\
\hline $342 \cdot 7$ & 340.7 & 8.88 & 14 \\
\hline 279.7 & $276 \cdot 4$ & 2.86 & 12 \\
\hline $273 \cdot 7$ & 285.9 & $4 \cdot 32$ & 10 \\
\hline $171 \cdot 1$ & $168 \cdot 3$ & $6 \cdot 75$ & 15 \\
\hline 139.9 & $137 \cdot 6$ & 3.91 & 12 \\
\hline 136.9 & $143 \cdot 1$ & $2 \cdot 84$ & 10 \\
\hline $85 \cdot 55$ & 83.71 & 8.64 & 16 \\
\hline 69.95 & $65 \cdot 21$ & 7.39 & 16 \\
\hline
\end{tabular}

silver iodate. Further, the minimal (final) concentrations of chloride which react with silver iodate are different in the two methods. In Sendroy's, it is
$0.1 \mathrm{M}$ (according to Judah, 1949); and in the present method, 0.0005 M (Table 1).

From a comparison of the figures in Tables 1 and 2 and from the serum chloride values by the two methods, it is seen that the present method and that of Wigglesworth are about equally accurate. Nevertheless, the iodometric procedure would appear

Table 3. Recovery of sodium chloride added to serum (Drop-scale iodometry.)

\begin{tabular}{|c|c|c|c|}
\hline \multicolumn{2}{|c|}{$\mathrm{NaCl}$ (m-equiv./l.) } & \multicolumn{2}{|c|}{$\mathrm{NaCl}$ (m-equiv./1.) } \\
\hline Added & Recovered & Added & Recovered \\
\hline $\begin{array}{l}299 \cdot 4 \\
239 \cdot 6 \\
179 \cdot 7 \\
119 \cdot 8\end{array}$ & $\begin{array}{l}285 \cdot 2 \\
228 \cdot 3 \\
175 \cdot 3 \\
122 \cdot 7\end{array}$ & $\begin{array}{l}59 \cdot 88 \\
29 \cdot 94 \\
23 \cdot 96 \\
17 \cdot 97\end{array}$ & $\begin{array}{l}60 \cdot 54 \\
31 \cdot 96 \\
24 \cdot 88 \\
17 \cdot 82\end{array}$ \\
\hline
\end{tabular}

to be more convenient for at least two reasons. It is less time consuming, and there is a sharp end point over a wider range of chloride concentrations.

\section{SUMMARY}

An adaptation of the Van Slyke and Hiller method has been described for the ultramicro determination of chloride.

My thanks are due to Dr N. K. Panikkar for his interest in this work and to the Chief Research Officer, Central Marine Fisheries Research Station, Mandapam Camp, for permission to publish this article.

\title{
REFERENCES
}

Glick, D. (1935). J. chem. Educ. 12, 253.

Judah, J. D. (1949). Biochem. J. 45, 60.

Sendroy, J. (1937). J. biol. Chem. 120, 335.
Van Slyke, D. D. \& Hiller, A. (1947). J. biol. Chem. 167, 107.

Wigglesworth, V. B. (1937). Biochem. J. 31, 1719.

\section{Improved Manometric Fluid}

\author{
BY H. A. KREBS \\ Medical Research Council Unit for Research in Cell Metabolism, \\ Department of Biochemistry, University of Sheffield
}

(Received 24 August 1950)

The manometric fluid in common use in Warburg manometers (Brodie, 1910; Warburg, 1912) contains bile salts to facilitate the free flow of the fluid in the capillary. Many of the wetting agents which have become available in recent years are much more effective than bile salts, and it is therefore possible to design an improved manometric fluid. In testing a series of detergents it was found that some compounds, e.g. alkyl sulphates and cetyltrimethyl- ammonium bromide, are liable to form a stable froth, and for this reason are not suitable for use in manometer fluids. Suitable substances were found among the non-ionic detergents, in particular among those arising by condensation of alkyl phenols with ethylene oxide, of the following general structure<smiles>CCCCOCCOc1ccc([14CH3])cc1</smiles> 